\title{
Data report: oxygen isotopes and foraminifer abundance record for the last glacial-interglacial cycle and marine isotope Stage 6 at IODP Site U1313'
}

M.E. Smith, ${ }^{2}$ E.V. Glick, ${ }^{2}$ S. Lodestro, ${ }^{3}$ and H. Rashid ${ }^{2,4}$

\section{Chapter contents}

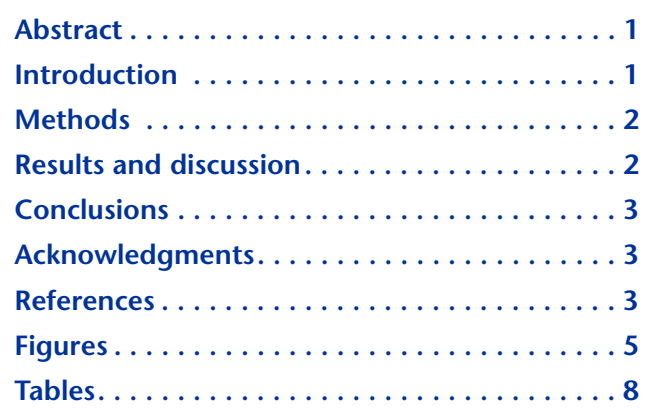

'Smith, M.E., Glick, E.V., Lodestro, S., and Rashid, H., 2013. Data report: oxygen isotopes and foraminifer abundance record for the last glacialinterglacial cycle and marine isotope Stage 6 at IODP Site U1313. In Channell, J.E.T., Kanamatsu, T., Sato, T., Stein, R., Alvarez Zarikian, C.A., Malone, M.J., and the Expedition 303/306 Scientists, Proc. IODP, 303/306: College Station, TX (Integrated Ocean Drilling Program Management International, Inc.).

doi:10.2204/iodp.proc.303306.216.2013

${ }^{2} S c h o o l$ of Earth Sciences, Ohio State University, Columbus $\mathrm{OH} 43210$, USA.

${ }^{3}$ Eckerd College, St. Petersburg FL 33711, USA.

${ }^{4}$ Also at: Memorial University of Newfoundland, 20 University Drive, Corner Brook, NL A2H 6P9,

Canada. hrashid@grenfell.mun.ca

\section{Abstract}

We determined oxygen isotope ratios $\left(\delta^{18} \mathrm{O}\right)$ of the mixed layerdwelling planktonic foraminifer Globigerina bulloides and relative abundance of Neogloboquadrina pachyderma (sinistral) for the last glacial-interglacial cycle, including marine isotope Stage (MIS) 6 from Integrated Ocean Drilling Program Site U1313. The $\delta^{18} \mathrm{O}$ data in G. bulloides allowed us to construct an age model. Changes in relative abundance of $N$. pachyderma (s) were compared to the $\delta^{18} \mathrm{O}$ of $G$. bulloides. We also performed a detailed quantitative study of four planktonic foraminiferal species to assess surface to near-surface oceanographic changes for the period between MIS 5 e and 6 (120-180 ka), including the penultimate glacial termination (TII). Analyses of the relative abundances of four planktonic foraminiferal species lead us to reconstruct the variability in the upper water masses of the North Atlantic at this subtropical site. We found clear indications of freshwater inputs, including a Heinrich iceberg-rafting event (H11), which provided a mechanism for freshening the sea surface and perturbing climate conditions.

\section{Introduction}

Data from planktonic foraminiferal assemblages have often been used to decipher past changes in sea-surface to near-sea surface conditions of the North Atlantic (Berggren, 1984; Weaver, 1987; Chapman et al., 2000). For example, the presence of polar surface water mass living species Neogloboquadrina pachyderma (sinistral), which dwells in subsurface water at present (Jonkers et al., 2010), at Integrated Ocean Drilling Program (IODP) Site U1313 suggests the presence of cold surface water conditions during the glacial period (Fairbanks et al., 1980; Raymo et al., 1989). In contrast, the presence of mixed-layer living Globigerina bulloides indicates subpolar to temperate conditions and has been implicated to the North Atlantic Current (NAC) (Ottens, 1991; van Kreveld, 1996). Neogloboquadrina incompta indicates subpolar conditions and is also associated with the NAC (van Kreveld, 1996). The transitional species Globorotalia inflata is assumed to thrive at the base of the thermocline and is associated with the NAC and the Gulf Stream (Kennett and Srinivasan, 1983; Ottens, 1991). Some of these species, however, also migrate and show preferential depth habitat that depends on temperature, salinity, and availability of food. As a result, the mere presence of these species cannot solely be correlated to surface climate conditions. In general, it is accepted 
that these foraminiferal assemblages can be used to infer changes in the surface to near-surface water conditions at Site U1313 (Raymo et al., 1989; Chapman et al., 2000).

In this study, a quantitative abundance analysis of $N$. pachyderma (s) and G. bulloides oxygen isotope ratios $\left(\delta^{18} \mathrm{O}\right)$ for marine isotope Stages (MISs) 1-6 were performed using sediment from Site U1313 (see the "Site U1313" chapter [Expedition 306 Scientists, 2006]). We also detailed quantitative abundances of four planktonic foraminifers to assess changes in the surface to near-surface water conditions during the penultimate deglaciation (130-140 ka) as well as MIS 6 (140-180 ka). Ice-rafted debris (IRD) data were used to infer sea-surface freshening, as meltwater perturbs sea-surface salinity.

\section{Methods}

Sediment samples from Site U1313 were wet sieved using a $>63 \mu \mathrm{m}$ sieve and sonicated for a few seconds to dislodge clay and other fine particles adhered to foraminifers. The washed residue $(>63 \mu \mathrm{m})$ was dried and then sieved again at $>150 \mu \mathrm{m}$ size fraction for foraminiferal and lithic fragment counts (Bond et al., 1993; Bond and Lotti, 1995). To obtain abundance counts of 300-600 foraminifers per gram of sediment, the dried residue ( $>150 \mu \mathrm{m}$ fraction) was split using a microsplitter. A number of splits was used in determining the relative abundance of each species based on estimated total foraminifers per sample. Using a binocular microscope, various species of planktonic foraminifers were identified and counted, including N. pachyderma (s), N. incompta, G. bulloides, and G. inflata (Bé and Tolderlund, 1971; Kennett and Srinivasan, 1983), and were used to estimate their relative abundances, which are relevant to ascertain various climate events and boundaries. In addition to foraminifers, lithic fragments were counted and normalized per gram of dry sediment and reported as IRD/g. IRD petrology such as detrital carbonate grains, quartz, feldspar, and so on were assessed to identify a Heinrich iceberg-rafting event (H11) (Heinrich, 1988; Bond et al., 1993).

Stable oxygen isotope ratios were determined on $G$. bulloides in the 150-250 $\mu \mathrm{m}$ size fraction. Approximately 30 specimens of $G$. bulloides were picked to ensure enough weight for mass spectrometer analysis and for future use in replicating isotopic analysis. Each sample was analyzed for $\delta^{18} \mathrm{O}$ relative to $\mathrm{Na}$ tional Bureau of Standards (NBS) 18, 19, and 20 standards using an automated carbonate Kiel extraction device coupled to a Finnigan Delta IV Plus stable isotope ratio mass spectrometer (Rashid et al., 2012). Samples were acidified under vacuum with 100\% ortho-phosphoric acid. Resulting $\mathrm{CO}_{2}$ was cryogenically purified and delivered to the mass spectrometer. Approximately $10 \%$ of all samples were run in duplicate. The standard deviation of repeated measurements of an internal standard was $\pm 0.06 \%$ for $\delta^{18} \mathrm{O}$. The age model of Site U1313 was constructed by matching the curve of $G$. bulloides $\delta^{18} \mathrm{O}$ with those of the global benthic foraminiferal $\delta^{18} \mathrm{O}$ stack (Lisiecki and Raymo, 2005). We used 20 control points, in which high and low G. bulloides $\delta^{18} \mathrm{O}$ values were correlated to those of the high and low $\delta^{18} \mathrm{O}$ values of the global benthic stack.

\section{Results and discussion}

The G. bulloides $\delta^{18} \mathrm{O}$ data between the core top and 9.4 meters composite depth (mcd) below seafloor show that this interval contains climate records from MISs 1-6. G. bulloides $\delta^{18} \mathrm{O}$ values range between $0.35 \%$ and $3.02 \%$, in which lower (or more depleted) values were associated with the interglaciation or interstadial periods. In contrast, higher (or more enriched) values were correlated to the glacial or stadial periods (Fig. F1). We resolved major climate transitions of the last glacial-interglacial cycle, including the Terminations TI and TII at 0.65 and 6.45 mcd, respectively. Abundances of N. pachyderma (s) vary from $0 \%$ to $18 \%$, and high values are always associated with Heinrich iceberg-rafting events in this region (Chapman et al., 2000; Rashid and Boyle, 2007; Naafs et al., 2011). See Tables T1 and T2 for quantitative data.

Abundances of four planktonic foraminifers and IRD/g data from 6 to 9.5 mcd are plotted in Figure F2. This depth range covers the climate interval from MISs 5e to 6 (Fig. F3A) (see the "Site U1313" chapter [Expedition 306 Scientists, 2006]). High-resolution G. bulloides $\delta^{18} \mathrm{O}$ data show a typical deglacial sequence from MISs 5e to 6 in which higher $\delta^{18} \mathrm{O}$ values were found in glacial MIS 6 and lower values were associated with MIS 5e (Fig. F3B). The gradual change from higher to lower $\delta^{18} \mathrm{O}$ values between the isotope stages was identified at Termination TII (Fig. F3B). More positive G. bulloides $\delta^{18} \mathrm{O}$ values (Fig. F2) were found in MIS 6 compared to MIS 5e, and $\delta^{18} \mathrm{O}$ values progressively became more positive from 194 to $156 \mathrm{ka}$ (i.e., from 9.21 to $7.32 \mathrm{mcd}$ ). The most positive $\delta^{18} \mathrm{O}$ values were obtained between 156 and $132 \mathrm{ka}$ (i.e., between 7.32 and $6.55 \mathrm{mcd}$ ) during the coldest part of MIS 6. The nature of the $\delta^{18} \mathrm{O}$ curve shows a more gradual transition at Termination TII compared to Termination TI at Site U1313, in which a rapid transition from glacial to interglacial state is observed.

Four IRD peaks were identified in MIS 6 (Fig. F2). Event H11 was identified halfway through Termination TII. 
However, the mean IRD/g in some peaks of MIS 6, such as at $8.40 \mathrm{mcd}$, was higher than Event H11 (Ruddiman, 1977; Chapman and Shackleton, 1998). The four IRD/g peaks in MIS 6 at Site U1313 are consistent with the high-resolution records from the southern Portuguese margin (Margari et al., 2010) and correspond to more negative $\delta^{18} \mathrm{O}$ values of planktonic foraminifers suggestive of sea-surface salinity dilution.

N. pachyderma (s) (Fig. F2) remains low in abundance $(<5 \%)$ throughout MIS 6 and rapidly decreases at the onset of Termination TII. It reaches a maximum of $10 \%$ abundance at the end (131-130.4 ka) of Event H11, thus doubling its highest glacial abundance. $G$. bulloides maintains a variable presence throughout MIS 6, reaching a maximum of nearly $40 \%$ abundance during Event $\mathrm{H} 11$ with a broad peak centered at $160 \mathrm{ka}$. The abundance curves of G. bulloides and $N$. pachyderma (s) generally follow each other. The subtropical location of Site U1313 is normally unsuitable for N. pachyderma (s) to dwell under modern climate conditions (Fairbanks et al., 1980), but the cold conditions during IRD events created a suitable environment for this species.

The baseline concentration of $N$. incompta hovers at $5 \%$ throughout MIS 5e to 6 , with four dominant peaks reaching as high as $26 \%$ with two other minor peaks. It seems that the overall concentration of $N$. incompta is anticorrelated with the abundances of $G$. bulloides and $N$. pachyderma (s), which is consistent with the findings of Chapman at al. (2000) from nearby Core SU90-03 (Fig. F2). However, N. incompta concentration shows positive correlation with $G$. inflata during the latter part of MIS $6(6.65-6.97 \mathrm{mcd})$.

G. inflata (Fig. F2) increases in late MIS 6 (155$134 \mathrm{ka}$ ) to nearly $14 \%$, compared to $<2 \%$ abundance from the earlier part of MIS 6. At the onset of Event H11, it decreases abruptly and reaches a minimum of $\sim 4 \%$. At the end of Event H11, it increases rapidly, reaching close to $16 \%$ abundance in MIS 5e. G. inflata exists in low abundance at Site U1313 throughout MIS 6.

Distinct changes in N. pachyderma (s), N. incompta, G. bulloides, and G. inflata abundances were found during Event H11. This event could have been associated with freshening and/or temporary cooling of the sea surface. Sea-surface cooling is substantiated by the presence of polar water mass indicator species N. pachyderma (s) (Bond et al., 1993) and low abundances of $N$. incompta. On the other hand, the high abundance of $G$. bulloides may indicate limited influence of polar water, which is consistent with the relatively low abundances of $N$. pachyderma (s). If the surface water was totally of polar to subpolar origin, then $N$. incompta should have also peaked in abun- dance. The high abundance of G. bulloides (a species that is very much food driven) may indicate that there was a mixture of polar and transitional water influencing Site U1313, with a warmer sea surface during Event H11 similar to the younger Heinrich iceberg-rafting events as observed by Naafs et al. (2013). This was further demonstrated by the sharp decline of temperate species $G$. inflata (Kucera et al., 2005). The warmer sea-surface conditions of MIS 5e were marked by the increase of $G$. inflata and subsequent decline in G. bulloides and N. incompta.

The high sensitivity of $N$. pachyderma (s) to Heinrich iceberg-rafting events was attributed to its polar water habitat (Bond et al., 1993). The peaks in N. pachyderma (s), N. incompta, and G. bulloides at Site U1313 suggest that the freshwater event (H11) cooled the sea surface, thus allowing these species to reach a temporary peak in abundance. At Site U1313, higher percentages of $G$. bulloides may coincide with higher availability of food.

\section{Conclusions}

Paleoproxy records allowed us to reconstruct changes in the upper water mass conditions in the North Atlantic from MISs 5e to 6 at subtropical Site U1313. Planktonic foraminifers were well-linked to climatic and environmental conditions in this area and serve as a paleoproxy. Changes in sea-surface conditions and ensuing water masses were reflected by changes in foraminifer relative abundances. Iceberg input was inferred by the presence of IRD. We identified Event $\mathrm{H} 11$ at Site U1313, which was associated with a freshwater release and ensuing perturbation of sea-surface conditions. The warmest seasurface conditions appear in phase with interglacial MIS 5e and the coolest conditions appear in phase with glacial MIS 6 .

\section{Acknowledgments}

Part of this work is supported through grants to Harunur Rashid from the US Science Support Program (USSSP). We acknowledge the Integrated Ocean Drilling Program (IODP) for providing samples for this study. The Biogeochemistry Laboratory of Ohio State University (USA) is thanked for analysis of stable isotopes.

\section{References}

Berggren, W.A., 1984. Neogene plankton foraminiferal biostratigraphy and biogeography: Atlantic, Mediterranean and Indo-Pacific regions. In Tsuchi, R., Ikebe, N., and IGCP Project 114 (Eds.), Pacific Neogene Datum Planes: 
Contributions to Biostratigraphy and Chronology: Tokyo (Univ. Tokyo Press), 111-161.

Bé, A.W.H., and Tolderlund, D.S., 1971. Distribution and ecology of living planktonic foraminifera in surface waters of the Atlantic and Indian Oceans. In Funnel, B.M., and Riedel, W.R. (Eds.), The Micropaleontology of Oceans: Cambridge (Cambridge Univ. Press), 105-149.

Bond, G., Broecker, W., Johnsen, S., McManus, J., Labeyrie, L., Jouzel, J., and Bonani, G., 1993. Correlations between climate records from North Atlantic sediments and Greenland ice. Nature (London, U. K.), 365(6442):143-147. doi:10.1038/365143a0

Bond, G.C., and Lotti, R., 1995. Iceberg discharges into the North Atlantic on millennial time scales during the last glaciation. Science, 267(5200):1005-1010. doi:10.1126/ science.267.5200.1005

Chapman, M.R., and Shackleton, N.J., 1998. Millennialscale fluctuations in North Atlantic heat flux during the last 150,000 years. Earth Planet. Sci. Lett., 159(1-2):5770. doi:10.1016/S0012-821X(98)00068-5

Chapman, M.R., Shackleton, N.J., and Duplessy, J.-C., 2000. Sea surface temperature variability during the last glacial-interglacial cycle: assessing the magnitude and pattern of climate change in the North Atlantic. Palaeogeogr., Palaeoclimatol., Palaeoecol., 157(1-2):1-25. doi:10.1016/S0031-0182(99)00168-6

Expedition 306 Scientists, 2006. Site U1313. In Channell, J.E.T., Kanamatsu, T., Sato, T., Stein, R., Alvarez Zarikian, C.A., Malone, M.J., and the Expedition 303/306 Scientists, Proc. IODP, 306: College Station, TX (Integrated Ocean Drilling Program Management International, Inc.). doi:10.2204/iodp.proc.303306.112.2006

Fairbanks, R.G., Wiebe, P.H., and Bé, A.W.H., 1980. Vertical distribution and isotopic composition of living planktonic foraminifera in the western North Atlantic. Science, 207(4426):61-63. doi:10.1126/

science.207.4426.61

Heinrich, H., 1988. Origin and consequences of cyclic ice rafting in the northeast Atlantic Ocean during the past 130,000 years. Quat. Res., 29(2):142-152. doi:10.1016/ 0033-5894(88)90057-9

Jonkers, L., Brummer, G.-J.A., Peeters, F.J.C., van Aken, H.M., and De Jong, M.F., 2010. Seasonal stratification, shell flux, and oxygen isotope dynamics of left-coiling N. pachyderma and T. quinqueloba in the western subpolar North Atlantic. Paleoceanography, 25(2):PA2204. doi:10.1029/2009pa001849

Kennett, J.P., and Srinivasan, M.S., 1983. Neogene Planktonic Foraminifera: A Phylogenetic Atlas: Stroudsburg, PA (Hutchinson Ross).

Kucera, M., Weinelt, M., Kiefer, T., Pflaumann, U., Hayes, A., Weinelt, M., Chen, M.-T., Mix, A.C., Barrows, T.T., Cortijo, E., Duprat, J., Juggins, S., and Waelbroeck, C., 2005. Reconstruction of sea-surface temperatures from assemblages of planktonic foraminifera: multi-technique approach based on geographically constrained calibration data sets and its application to glacial Atlantic and
Pacific Oceans. Quat. Sci. Rev., 24(7-9):951-998. doi:10.1016/j.quascirev.2004.07.014

Lisiecki, L.E., and Raymo, M.E., 2005. A Pliocene-Pleistocene stack of 57 globally distributed benthic $\delta^{18} \mathrm{O}$ records. Paleoceanography, 20(1):PA1003. doi:10.1029/ 2004PA001071

Margari, V., Skinner, L.C., Tzedakis, P.C., Ganopolski, A., Vautravers, M., and Shackleton, N.J., 2010. The nature of millennial-scale climate variability during the past two glacial periods. Nat. Geosci., 3(2):127-131. doi:10.1038/ngeo740

Naafs, B.D.A., Hefter, J., Ferretti, P., Stein, R., and Haug, G.H., 2011. Sea surface temperatures did not control the first occurrence of Hudson Strait Heinrich events during MIS 16. Paleoceanography, 26(4):PA4201. doi:10.1029/ 2011PA002135

Naafs, D.B.A., Hefter, J., Grützner, J., and Stein, R., 2013. Warming of surface waters in the mid-latitude North Atlantic during Heinrich events. Paleoceanography, 28(1):153-163. doi:10.1029/2012PA002354

Ottens, J.J., 1991. Planktonic foraminifera as North Atlantic water mass indicators. Oceanol. Acta, 14(2):123-140.

Rashid, H., and Boyle, E.A., 2007. Mixed-layer deepening during Heinrich events: a multi-planktonic foraminiferal $\delta^{18} \mathrm{O}$ approach. Science, 318(5849):439-441. doi:10.1126/science.1146138

Rashid, H., Saint-Ange, F., Barber, D.C., Smith, M.E., and Devalia, N., 2012. Fine scale sediment structure and geochemical signature between eastern and western North Atlantic during Heinrich Events 1 and 2. Quat. Sci. Rev., 46:136-150. doi:10.1016/j.quascirev.2012.04.026

Raymo, M.E., Ruddiman, W.F., Backman, J., Clement, B.M., and Martinson, D.G., 1989. Late Pliocene variation in Northern Hemisphere ice sheets and North Atlantic deep water circulation. Paleoceanography, 4(4):413-446. doi:10.1029/PA004i004p00413

Ruddiman, W.F., 1977. Late Quaternary deposition of icerafted sand in the subpolar North Atlantic (lat $40^{\circ} \mathrm{N}$ to $\left.65^{\circ} \mathrm{N}\right)$. Geol. Soc. Am. Bull., 88(12):1813-1827.

doi:10.1130/00167606(1977)88<1813:LQDOIS >2.0.CO;2

van Kreveld, S.A., 1996. Northeast Atlantic late Quaternary planktic foraminifera as primary productivity and water mass indicators. Scripta Geol., 113:23-91. http:// www.repository.naturalis.nl/document/148811

Weaver, P.P.E., 1987. Late Miocene to recent planktonic foraminifers from the North Atlantic: Deep Sea Drilling Project Leg 94. In Ruddiman, W.F., Kidd, R.B., Thomas, E., et al., Init. Repts. DSDP, 94: Washington (U.S. Govt. Printing Office), 703-727. doi:10.2973/ dsdp.proc.94.114.1987

Initial receipt: 27 November 2012

Acceptance: 6 June 2013

Publication: 30 August 2013

MS 303306-216 
Figure F1. Globigerina bulloides oxygen isotopes $\left(\delta^{18} \mathrm{O}\right)$ and relative abundance of Neogloboquadrina pachyderma (sinistral) versus depth, Site U1313. Shaded area between 6.3 and 9.7 mcd represents MISs 5e and 6 interval in which high-resolution data are plotted in Figure F2.

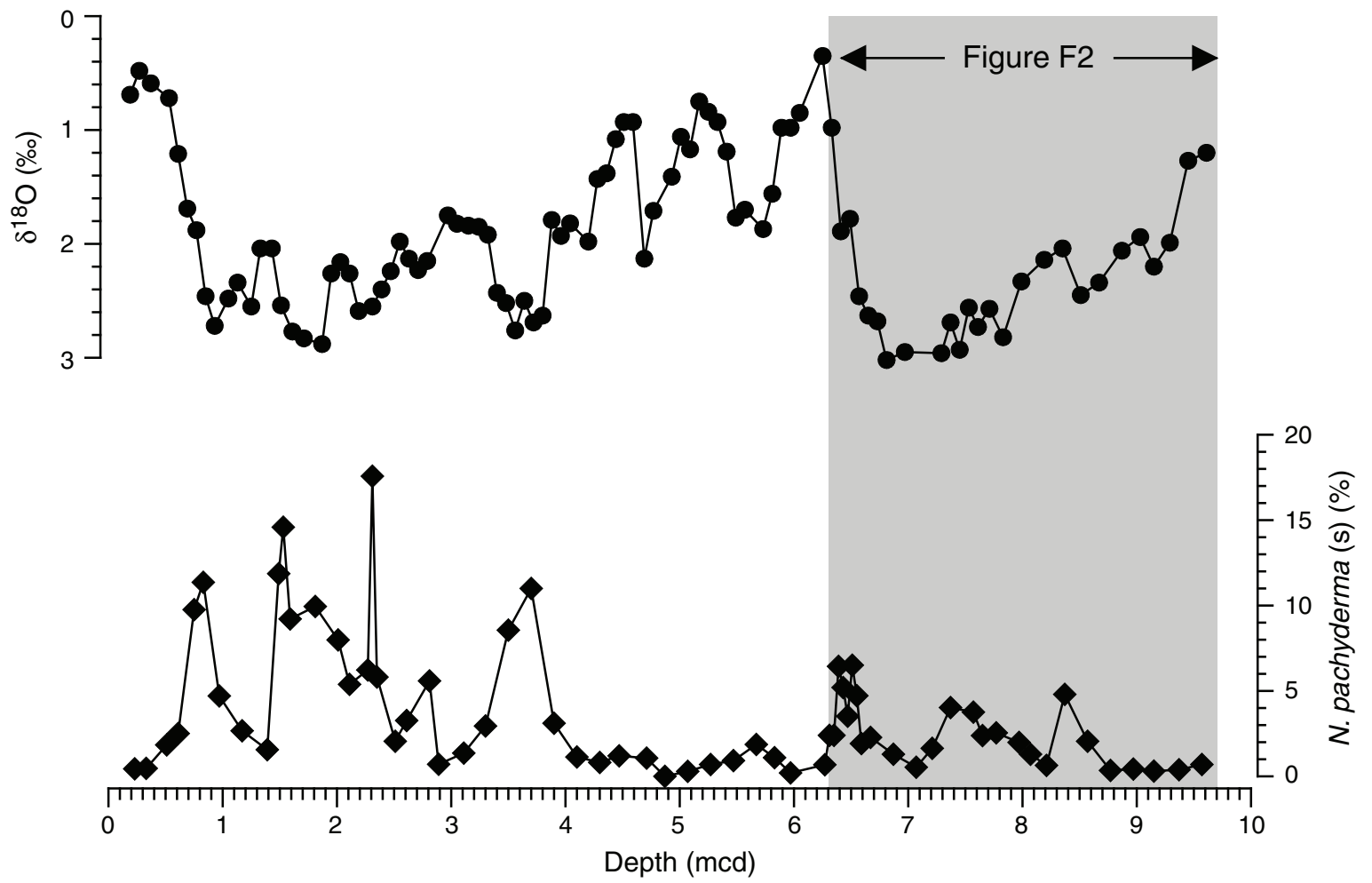


Figure F2. Plots of ice-rafted debris (IRD)/g, Neogloboquadrina pachyderma (s), Neogloboquadrina incompta, Globigerina bulloides, and Globorotalia inflata shown as a function of composite depth, Site U1313. Event H11 coincides with a peak in G. bulloides and a low abundance of $G$. inflata. The peak of N. pachyderma (s) is offset from Event H11.

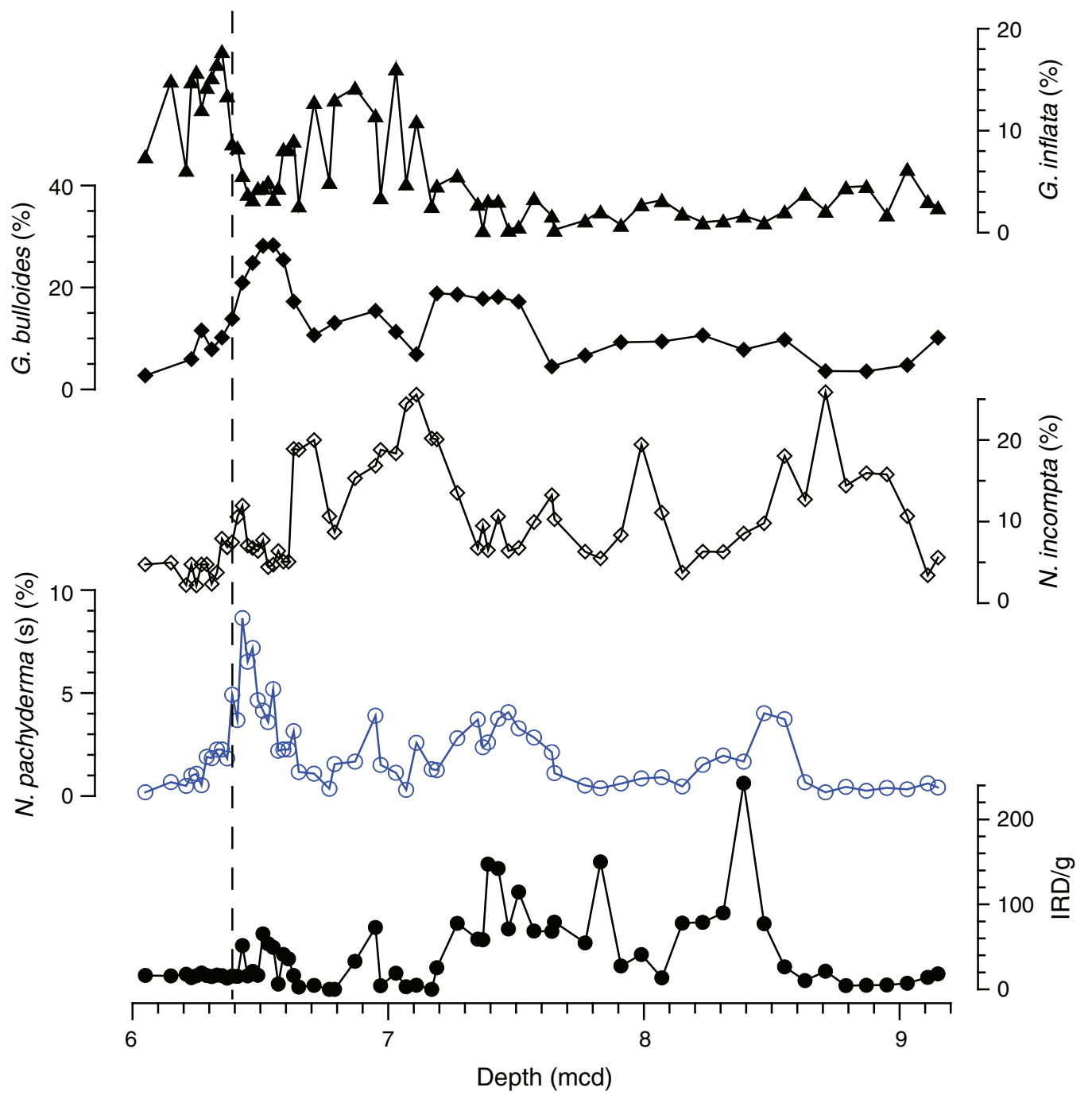


Figure F3. A. Abundances of four planktonic foraminifers and ice-rafted debris (IRD)/g plotted as a function of age for the interval encompassing marine isotope stages (MISs) 5e and 6. Note the shaded bar indicates Event $\mathrm{H} 11$. B. Plots of Neogloboquadrina pachyderma (s) data and Globigerina bulloides oxygen isotopes $\left(\delta^{18} \mathrm{O}\right)$ shown as a function of age. Age model was constructed by matching $\delta^{18} \mathrm{O}$ values with the global benthic $\delta^{18} \mathrm{O}$ stack of Lisiecki and Raymo (2005) (LR-2005 stack).

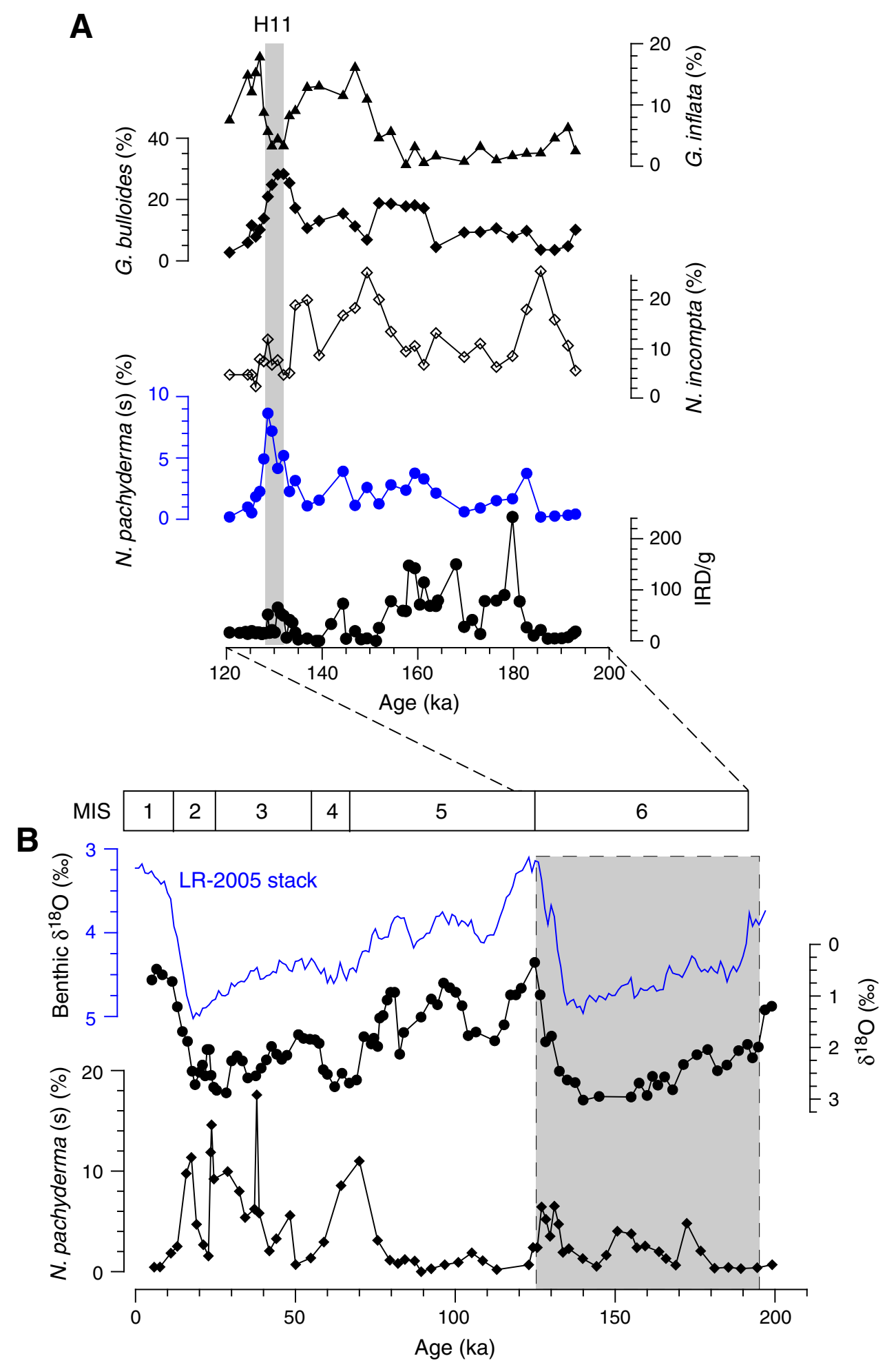


Table T1. $\delta^{18} \mathrm{O}$ of Globigerina bulloides and percent Neogloboquadrina pachyderma (sinistral) data. (Continued on next two pages.)

\begin{tabular}{|c|c|c|c|}
\hline $\begin{array}{l}\text { Core, section, } \\
\text { interval }(\mathrm{cm})\end{array}$ & $\begin{array}{l}\text { Depth } \\
\text { (mcd) }\end{array}$ & $\begin{array}{c}\text { Globigerina bulloides } \\
\delta^{18} \mathrm{O}(\% \mathrm{o})\end{array}$ & $\begin{array}{c}\text { Neogloboquadrina } \\
\text { pachyderma (sinistral) } \\
(\%)\end{array}$ \\
\hline \multicolumn{4}{|l|}{ 306-U1313A- } \\
\hline $1 \mathrm{H}-1,0-2$ & 0.19 & 0.69 & \\
\hline $1 \mathrm{H}-1,4-6$ & 0.23 & & 0.445 \\
\hline $1 \mathrm{H}-1,8-10$ & 0.27 & 0.48 & \\
\hline $1 \mathrm{H}-1,14-16$ & 0.33 & & 0.465 \\
\hline $1 \mathrm{H}-1,16-18$ & 0.35 & 0.78 & \\
\hline $1 \mathrm{H}-1,30-32$ & 0.49 & 0.86 & \\
\hline $1 \mathrm{H}-1,32-34$ & 0.51 & & 1.839 \\
\hline $1 \mathrm{H}-1,40-42$ & 0.59 & 0.61 & \\
\hline $1 \mathrm{H}-1,42-44$ & 0.61 & & 2.510 \\
\hline $1 \mathrm{H}-1,50-52$ & 0.69 & 1.69 & \\
\hline $1 \mathrm{H}-1,56-58$ & 0.75 & 1.97 & 9.756 \\
\hline $1 \mathrm{H}-1,64-66$ & 0.83 & & 11.357 \\
\hline $1 \mathrm{H}-1,66-68$ & 0.85 & 2.46 & \\
\hline $1 \mathrm{H}-1,72-74$ & 0.91 & 2.32 & \\
\hline $1 \mathrm{H}-1,78-80$ & 0.97 & & 4.706 \\
\hline $1 \mathrm{H}-1,80-82$ & 0.99 & 2.63 & \\
\hline $1 \mathrm{H}-1,90-92$ & 1.09 & 2.43 & \\
\hline $1 \mathrm{H}-1,96-98$ & 1.15 & 2.66 & \\
\hline $1 \mathrm{H}-1,98-100$ & 1.17 & & 2.672 \\
\hline $1 \mathrm{H}-1,104-106$ & 1.23 & 1.95 & \\
\hline $1 \mathrm{H}-1,112-114$ & 1.31 & 2.80 & \\
\hline $1 \mathrm{H}-1,120-122$ & 1.39 & & 1.559 \\
\hline $1 \mathrm{H}-1,122-124$ & 1.41 & 2.11 & \\
\hline $1 \mathrm{H}-1,130-132$ & 1.49 & 2.40 & 11.872 \\
\hline $1 \mathrm{H}-1,134-136$ & 1.53 & & 14.589 \\
\hline $1 \mathrm{H}-1,140-142$ & 1.59 & 2.74 & 9.211 \\
\hline \multicolumn{4}{|l|}{ 306-U1313B- } \\
\hline $2 \mathrm{H}-2,0-2$ & 1.71 & 2.83 & \\
\hline $1 \mathrm{H}-2,10-12$ & 1.81 & 3.03 & 9.949 \\
\hline $1 \mathrm{H}-2,18-20$ & 1.89 & 2.99 & \\
\hline $1 \mathrm{H}-2,30-32$ & 2.01 & 2.70 & 7.988 \\
\hline $1 \mathrm{H}-2,34-36$ & 2.05 & 2.55 & \\
\hline $1 \mathrm{H}-2,40-42$ & 2.11 & & 5.385 \\
\hline $1 \mathrm{H}-2,42-44$ & 2.13 & 2.75 & \\
\hline $1 \mathrm{H}-2,52-54$ & 2.23 & 2.57 & \\
\hline $1 \mathrm{H}-2,56-58$ & 2.27 & & 6.225 \\
\hline $1 \mathrm{H}-2,60-62$ & 2.31 & & 17.577 \\
\hline $1 \mathrm{H}-2,62-64$ & 2.33 & 2.49 & \\
\hline $1 \mathrm{H}-2,64-66$ & 2.35 & & 5.817 \\
\hline $1 \mathrm{H}-2,70-72$ & 2.41 & 2.73 & \\
\hline $1 \mathrm{H}-2,78-80$ & 2.49 & 2.51 & \\
\hline $1 \mathrm{H}-2,80-82$ & 2.51 & & 2.059 \\
\hline $1 \mathrm{H}-2,86-88$ & 2.57 & 2.26 & \\
\hline $1 \mathrm{H}-2,90-92$ & 2.61 & & 3.267 \\
\hline $1 \mathrm{H}-2,94-96$ & 2.65 & 1.99 & \\
\hline $1 \mathrm{H}-2,102-104$ & 2.73 & 2.38 & \\
\hline $1 \mathrm{H}-2,110-112$ & 2.81 & 2.16 & 5.588 \\
\hline $1 \mathrm{H}-2,118-120$ & 2.89 & & 0.706 \\
\hline $1 \mathrm{H}-2,124-126$ & 2.95 & 1.69 & \\
\hline $1 \mathrm{H}-2,130-132$ & 3.01 & 1.52 & \\
\hline $1 \mathrm{H}-2,140-142$ & 3.11 & & 1.360 \\
\hline $1 \mathrm{H}-2,142-144$ & 3.13 & 1.88 & \\
\hline $3 \mathrm{H}-3,0-2$ & 3.22 & 2.70 & \\
\hline $3 \mathrm{H}-3,10-12$ & 3.30 & 2.24 & 2.941 \\
\hline $3 \mathrm{H}-3,18-20$ & 3.38 & 2.58 & \\
\hline $3 \mathrm{H}-3,26-28$ & 3.46 & 2.56 & \\
\hline $3 \mathrm{H}-3,30-32$ & 3.50 & & 8.555 \\
\hline $3 \mathrm{H}-3,3436$ & 3.54 & 2.76 & \\
\hline $3 \mathrm{H}-3,42-44$ & 3.62 & 2.50 & \\
\hline $3 \mathrm{H}-3,48-50$ & 3.68 & 2.90 & \\
\hline $3 \mathrm{H}-3,50-52$ & 3.70 & & 11.000 \\
\hline $3 \mathrm{H}-3,58-60$ & 3.78 & 2.76 & \\
\hline $3 \mathrm{H}-3,66-68$ & 3.86 & 2.57 & \\
\hline $3 \mathrm{H}-3,70-72$ & 3.90 & & 3.113 \\
\hline $3 \mathrm{H}-3,74-76$ & 3.94 & 2.10 & \\
\hline
\end{tabular}


Table T1 (continued). (Continued on next page.)

\begin{tabular}{|c|c|c|c|}
\hline $\begin{array}{l}\text { Core, section, } \\
\text { interval }(\mathrm{cm})\end{array}$ & $\begin{array}{l}\text { Depth } \\
\text { (mcd) }\end{array}$ & $\begin{array}{c}\text { Globigerina bulloides } \\
\delta^{18} \mathrm{O}(\% \mathrm{o})\end{array}$ & $\begin{array}{c}\text { Neogloboquadrina } \\
\text { pachyderma (sinistral) } \\
\text { (\%) }\end{array}$ \\
\hline $3 \mathrm{H}-3,82-84$ & 4.02 & 1.78 & \\
\hline $3 \mathrm{H}-3,92-94$ & 4.10 & 1.83 & 1.139 \\
\hline $3 \mathrm{H}-3,98-100$ & 4.18 & 2.30 & \\
\hline $3 \mathrm{H}-3,106-108$ & 4.26 & 1.62 & \\
\hline $3 \mathrm{H}-3,110-112$ & 4.30 & & 0.813 \\
\hline $3 \mathrm{H}-3,114-116$ & 4.34 & 1.84 & \\
\hline $3 \mathrm{H}-3,122-124$ & 4.42 & 1.68 & \\
\hline $3 \mathrm{H}-3,126-128$ & 4.47 & & 1.205 \\
\hline \multicolumn{4}{|l|}{ 306-U1313C- } \\
\hline $2 \mathrm{H}-1,134-136$ & 4.49 & 1.23 & \\
\hline $2 \mathrm{H}-1,142-144$ & 4.57 & 1.65 & \\
\hline $2 \mathrm{H}-2,0-2$ & 4.65 & 2.06 & \\
\hline $2 \mathrm{H}-2,4-6$ & 4.71 & 1.061 & \\
\hline $2 \mathrm{H}-2,8-10$ & 4.75 & 2.14 & \\
\hline $2 \mathrm{H}-2,16-18$ & 4.83 & 1.21 & \\
\hline $2 \mathrm{H}-2,20-22$ & 4.87 & 0.000 & \\
\hline $2 \mathrm{H}-2,26-28$ & 4.93 & 1.41 & \\
\hline $2 \mathrm{H}-2,34-36$ & 5.01 & 1.06 & \\
\hline $2 \mathrm{H}-2,40-42$ & 5.07 & 0.292 & \\
\hline $2 \mathrm{H}-2,42-44$ & 5.09 & 1.17 & \\
\hline $2 \mathrm{H}-2,50-52$ & 5.17 & 0.75 & \\
\hline $2 \mathrm{H}-2,58-60$ & 5.25 & 0.84 & \\
\hline $2 \mathrm{H}-2,60-62$ & 5.27 & & 0.690 \\
\hline $2 \mathrm{H}-2,66-68$ & 5.33 & 0.93 & \\
\hline $2 \mathrm{H}-2,74-76$ & 5.41 & 1.19 & \\
\hline $2 \mathrm{H}-2,80-82$ & 5.47 & & 0.922 \\
\hline $2 \mathrm{H}-2,82-84$ & 5.49 & 1.77 & \\
\hline $2 \mathrm{H}-2,90-92$ & 5.57 & 1.70 & \\
\hline $2 \mathrm{H}-2,100-102$ & 5.67 & 1.82 & 1.869 \\
\hline $2 \mathrm{H}-2,108-110$ & 5.75 & 1.99 & \\
\hline $2 \mathrm{H}-2,116-118$ & 5.83 & 0.95 & 1.091 \\
\hline $2 \mathrm{H}-2,124-126$ & 5.91 & 0.93 & \\
\hline $2 \mathrm{H}-2,130-132$ & 5.97 & & 0.202 \\
\hline $2 \mathrm{H}-2,134-136$ & 6.01 & 0.78 & \\
\hline $2 \mathrm{H}-3,2-4$ & 6.19 & 0.56 & \\
\hline $2 \mathrm{H}-3,10-12$ & 6.27 & & 0.673 \\
\hline $2 \mathrm{H}-3,12-14$ & 6.29 & 0.68 & \\
\hline $2 \mathrm{H}-3,14-16$ & 6.31 & & 2.404 \\
\hline $2 \mathrm{H}-3,18-20$ & 6.35 & & 2.400 \\
\hline $2 \mathrm{H}-3,20-22$ & 6.37 & 1.20 & \\
\hline $2 \mathrm{H}-3,22-24$ & 6.39 & & 6.436 \\
\hline $2 \mathrm{H}-3,26-28$ & 6.43 & & 5.202 \\
\hline $2 \mathrm{H}-3,30-32$ & 6.47 & 1.80 & 3.514 \\
\hline $2 \mathrm{H}-3,34-36$ & 6.51 & & 6.509 \\
\hline $2 \mathrm{H}-3,38-40$ & 6.55 & 1.80 & 4.717 \\
\hline $2 \mathrm{H}-3,40-42$ & 6.59 & & 1.916 \\
\hline $2 \mathrm{H}-3,42-44$ & 6.63 & 2.63 & \\
\hline $2 \mathrm{H}-3,50-52$ & 6.67 & & 2.286 \\
\hline $2 \mathrm{H}-3,54-56$ & 6.71 & 2.86 & \\
\hline $2 \mathrm{H}-3,64-66$ & 6.81 & 3.02 & \\
\hline $2 \mathrm{H}-3,70-72$ & 6.87 & & 1.296 \\
\hline $2 \mathrm{H}-3,80-82$ & 6.97 & 2.95 & \\
\hline $2 \mathrm{H}-3,90-92$ & 7.07 & & 0.533 \\
\hline $2 \mathrm{H}-3,104-106$ & 7.21 & & 1.639 \\
\hline $2 \mathrm{H}-3,108-110$ & 7.25 & 2.78 & \\
\hline $2 \mathrm{H}-3,116-118$ & 7.33 & 2.90 & \\
\hline $2 \mathrm{H}-3,120-122$ & 7.37 & & 4.023 \\
\hline $2 \mathrm{H}-3,124-126$ & 7.41 & 3.05 & \\
\hline $2 \mathrm{H}-3,132-134$ & 7.49 & 2.71 & \\
\hline $2 \mathrm{H}-3,140-142$ & 7.57 & 3.32 & 3.761 \\
\hline $2 \mathrm{H}-4,0-2$ & 7.65 & 2.67 & 2.387 \\
\hline $2 \mathrm{H}-4,8-10$ & 7.75 & 2.55 & \\
\hline $2 \mathrm{H}-4,10-12$ & 7.77 & & 2.548 \\
\hline $2 \mathrm{H}-4,24-26$ & 7.91 & 2.53 & \\
\hline $2 \mathrm{H}-4,30-32$ & 7.97 & & 1.984 \\
\hline $2 \mathrm{H}-4,40-42$ & 8.07 & 2.21 & 1.299 \\
\hline $2 \mathrm{H}-4,54-56$ & 8.21 & & 0.645 \\
\hline $2 \mathrm{H}-4,56-58$ & 8.23 & 2.07 & \\
\hline
\end{tabular}


Table T1 (continued).

\begin{tabular}{lccc}
\hline $\begin{array}{c}\text { Core, section, } \\
\text { interval }(\mathrm{cm})\end{array}$ & $\begin{array}{c}\text { Depth } \\
(\mathrm{mcd})\end{array}$ & $\begin{array}{c}\text { Globigerina bulloides } \\
\delta^{18} \mathrm{O}(\%)\end{array}$ & $\begin{array}{c}\text { Neogloboquadrina } \\
\text { pachyderma (sinistral) } \\
(\%)\end{array}$ \\
\hline $2 \mathrm{H}-4,70-72$ & 8.37 & & 4.805 \\
$2 \mathrm{H}-4,76-78$ & 8.43 & 2.63 & 2.059 \\
$2 \mathrm{H}-4,90-92$ & 8.57 & & \\
$2 \mathrm{H}-4,92-94$ & 8.59 & 2.59 & 0.342 \\
$2 \mathrm{H}-4,110-112$ & 8.77 & & \\
$2 \mathrm{H}-4,112-114$ & 8.79 & 2.50 & \\
$2 \mathrm{H}-4,128-130$ & 8.95 & 1.63 & \\
$2 \mathrm{H}-4,130-132$ & 8.97 & & \\
$2 \mathrm{H}-4,144-146$ & 9.11 & 1.24 & \\
$2 \mathrm{H}-4,148-150$ & 9.15 & & \\
$2 \mathrm{H}-5,4-6$ & 9.21 & 2.00 & 0.324 \\
$2 \mathrm{H}-5,12-14$ & 9.29 & 1.99 & \\
$2 \mathrm{H}-5,20-22$ & 9.37 & & \\
$2 \mathrm{H}-5,38-40$ & 9.55 & 1.70 & 0.392 \\
$2 \mathrm{H}-5,40-42$ & 9.57 & & \\
$2 \mathrm{H}-5,50-52$ & 9.67 & 1.61 & \\
$2 \mathrm{H}-5,60-62$ & 9.77 & & \\
$2 \mathrm{H}-5,68-70$ & 9.85 & 1.92 & \\
$2 \mathrm{H}-5,80-82$ & 9.97 & 1.79 & \\
\hline
\end{tabular}

Table T2. Ice-rafted debris/g and relative abundances of planktonic foraminifers Neogloboquadrina pachyderma (sinistral), Neogloboquadrina incompta, Globigerina bulloides, and Globorotalia inflata data. (Continued on next page.)

\begin{tabular}{|c|c|c|c|c|c|c|}
\hline $\begin{array}{l}\text { Core, section, } \\
\text { interval }(\mathrm{cm})\end{array}$ & $\begin{array}{l}\text { Depth } \\
\text { (mcd) }\end{array}$ & $\begin{array}{l}\text { Ice-rafted } \\
\text { debris } / g\end{array}$ & $\begin{array}{c}\text { Neogloboquadrina } \\
\text { pachyderma (sinistral) } \\
\text { (\%) }\end{array}$ & $\begin{array}{l}\text { Neogloboquadrina } \\
\text { incompta (\%) }\end{array}$ & $\begin{array}{c}\text { Globigerina } \\
\text { bulloides (\%) }\end{array}$ & $\begin{array}{l}\text { Globorotalia } \\
\text { inflata (\%) }\end{array}$ \\
\hline \multicolumn{7}{|l|}{ 306-U1313C- } \\
\hline $2 \mathrm{H}-2,98-100$ & 5.65 & 6.40 & 1.13 & 6.20 & 8.27 & 2.63 \\
\hline $2 \mathrm{H}-2,100-102$ & 5.67 & 8.78 & 1.67 & 3.13 & 10.63 & 11.88 \\
\hline $2 \mathrm{H}-2,104-106$ & 5.71 & 45.11 & 1.36 & 4.48 & 10.53 & 1.95 \\
\hline $2 \mathrm{H}-2,110-112$ & 5.77 & 9.23 & 3.38 & 6.49 & 20.26 & 10.65 \\
\hline $2 \mathrm{H}-2,112-114$ & 5.79 & 9.83 & 0.26 & 4.18 & 9.66 & 3.66 \\
\hline $2 \mathrm{H}-2,114-116$ & 5.81 & 8.28 & 0.58 & 8.70 & 9.48 & 11.99 \\
\hline $2 \mathrm{H}-2,120-122$ & 5.87 & 14.76 & 0.18 & 5.35 & 11.25 & 14.94 \\
\hline $2 \mathrm{H}-2,122-124$ & 5.89 & 6.61 & 0.26 & 4.96 & 7.57 & 16.97 \\
\hline $2 \mathrm{H}-2,126-128$ & 5.93 & 8.55 & 0.18 & 3.01 & 10.62 & 19.12 \\
\hline $2 \mathrm{H}-2,128-130$ & 5.95 & 7.79 & 0.54 & 4.83 & 3.94 & 6.44 \\
\hline $2 \mathrm{H}-2,130-132$ & 5.97 & 13.66 & 0.28 & 7.50 & 9.44 & 23.06 \\
\hline $2 \mathrm{H}-2,134-136$ & 6.01 & 15.33 & 0.57 & 3.72 & 3.72 & 23.21 \\
\hline $2 \mathrm{H}-2,138-140$ & 6.05 & 16.43 & 0.18 & 4.74 & 2.74 & 7.48 \\
\hline $2 \mathrm{H}-3,0-2$ & 6.15 & 15.80 & 0.68 & 4.97 & 6.32 & 14.90 \\
\hline $2 \mathrm{H}-3,4-6$ & 6.21 & 17.75 & 0.49 & 2.22 & 5.67 & 6.16 \\
\hline $2 \mathrm{H}-3,6-8$ & 6.23 & 13.73 & 0.99 & 4.74 & 5.93 & 14.82 \\
\hline $2 \mathrm{H}-3,8-10$ & 6.25 & 16.02 & 1.08 & 2.16 & 8.21 & 15.77 \\
\hline $2 \mathrm{H}-3,10-12$ & 6.27 & 19.17 & 0.53 & 4.74 & 11.58 & 12.11 \\
\hline $2 \mathrm{H}-3,12-14$ & 6.29 & 16.32 & 1.90 & 4.76 & 8.25 & 14.29 \\
\hline $2 \mathrm{H}-3,14-16$ & 6.31 & 15.00 & 1.84 & 2.36 & 7.87 & 15.22 \\
\hline $2 \mathrm{H}-3,16-18$ & 6.33 & 16.78 & 2.26 & 3.76 & 10.03 & 16.54 \\
\hline $2 \mathrm{H}-3,18-20$ & 6.35 & 16.11 & 2.26 & 7.91 & 10.17 & 17.80 \\
\hline $2 \mathrm{H}-3,20-22$ & 6.37 & 13.23 & 1.83 & 6.85 & 11.42 & 13.47 \\
\hline $2 \mathrm{H}-3,22-24$ & 6.39 & 15.67 & 4.92 & 7.47 & 13.84 & 8.74 \\
\hline $2 \mathrm{H}-3,24-26$ & 6.41 & 15.25 & 3.69 & 10.57 & 15.72 & 8.35 \\
\hline $2 \mathrm{H}-3,26-28$ & 6.43 & 51.54 & 8.64 & 11.96 & 20.93 & 5.65 \\
\hline $2 \mathrm{H}-3,28-30$ & 6.45 & 15.84 & 6.52 & 7.07 & 28.80 & 3.80 \\
\hline $2 \mathrm{H}-3,30-32$ & 6.47 & 21.21 & 7.19 & 6.75 & 24.84 & 3.27 \\
\hline $2 \mathrm{H}-3,32-34$ & 6.49 & 16.59 & 4.65 & 6.40 & 26.16 & 4.36 \\
\hline $2 \mathrm{H}-3,34-36$ & 6.51 & 65.30 & 4.14 & 7.73 & 28.18 & 4.42 \\
\hline $2 \mathrm{H}-3,36-38$ & 6.53 & 53.66 & 3.59 & 4.42 & 37.57 & 4.97 \\
\hline $2 \mathrm{H}-3,38-40$ & 6.55 & 49.40 & 5.19 & 4.72 & 28.30 & 3.30 \\
\hline $2 \mathrm{H}-3,40-42$ & 6.57 & 6.25 & 2.20 & 6.39 & 31.50 & 4.41 \\
\hline $2 \mathrm{H}-3,42-44$ & 6.59 & 41.05 & 2.26 & 5.08 & 25.42 & 8.19 \\
\hline $2 \mathrm{H}-3,44-46$ & 6.61 & 35.88 & 2.26 & 5.08 & 25.42 & 8.19 \\
\hline
\end{tabular}


Table T2 (continued).

\begin{tabular}{|c|c|c|c|c|c|c|}
\hline $\begin{array}{l}\text { Core, section, } \\
\text { interval }(\mathrm{cm})\end{array}$ & $\begin{array}{l}\text { Depth } \\
\text { (mcd) }\end{array}$ & $\begin{array}{l}\text { Ice-rafted } \\
\text { debris/g }\end{array}$ & $\begin{array}{c}\text { Neogloboquadrina } \\
\text { pachyderma (sinistral) } \\
(\%)\end{array}$ & $\begin{array}{l}\text { Neogloboquadrina } \\
\text { incompta (\%) }\end{array}$ & $\begin{array}{c}\text { Globigerina } \\
\text { bulloides (\%) }\end{array}$ & $\begin{array}{c}\text { Globorotalia } \\
\text { inflata (\%) }\end{array}$ \\
\hline $2 \mathrm{H}-3,46-48$ & 6.63 & 16.28 & 3.15 & 18.91 & 17.23 & 9.03 \\
\hline $2 \mathrm{H}-3,48-50$ & 6.65 & 2.69 & 1.16 & 18.80 & 12.48 & 2.66 \\
\hline $2 \mathrm{H}-3,54-56$ & 6.71 & 4.68 & 1.09 & 20.00 & 10.65 & 12.83 \\
\hline $2 \mathrm{H}-3,60-62$ & 6.77 & 0.00 & 0.36 & 10.66 & 8.88 & 4.97 \\
\hline $2 \mathrm{H}-3,62-64$ & 6.79 & 0.00 & 1.55 & 8.70 & 13.04 & 13.04 \\
\hline $2 \mathrm{H}-3,70-72$ & 6.87 & 33.01 & 1.67 & 15.32 & 12.53 & 14.21 \\
\hline $2 \mathrm{H}-3,78-80$ & 6.95 & 72.86 & 3.90 & 16.84 & 15.40 & 11.50 \\
\hline $2 \mathrm{H}-3,80-82$ & 6.97 & 4.25 & 1.51 & 18.79 & 9.07 & 3.46 \\
\hline $2 \mathrm{H}-3,86-88$ & 7.03 & 19.05 & 1.13 & 18.36 & 11.30 & 16.10 \\
\hline $2 \mathrm{H}-3,90-92$ & 7.07 & 3.04 & 0.30 & 24.40 & 6.63 & 4.82 \\
\hline $2 \mathrm{H}-3,94-96$ & 7.11 & 4.87 & 2.59 & 25.57 & 6.90 & 10.92 \\
\hline $2 \mathrm{H}-3,100-102$ & 7.17 & 0.00 & 1.30 & 20.20 & 17.26 & 2.61 \\
\hline $2 \mathrm{H}-3,102-104$ & 7.19 & 25.42 & 1.26 & 20.08 & 18.83 & 4.60 \\
\hline $2 \mathrm{H}-3,110-112$ & 7.27 & 77.65 & 2.81 & 13.52 & 18.62 & 5.61 \\
\hline $2 \mathrm{H}-3,118-120$ & 7.35 & 59.00 & 3.72 & 6.73 & 18.05 & 2.83 \\
\hline $2 \mathrm{H}-3,120-122$ & 7.37 & 58.33 & 2.37 & 9.48 & 17.77 & 0.24 \\
\hline $2 \mathrm{H}-3,122-124$ & 7.39 & 147.38 & 2.60 & 6.49 & 18.18 & 3.12 \\
\hline $2 \mathrm{H}-3,126-128$ & 7.43 & 142.20 & 3.75 & 10.63 & 18.13 & 3.13 \\
\hline $2 \mathrm{H}-3,130-132$ & 7.47 & 71.08 & 4.07 & 6.40 & 13.95 & 0.29 \\
\hline $2 \mathrm{H}-3,134-136$ & 7.51 & 114.56 & 3.29 & 6.77 & 17.21 & 0.58 \\
\hline $2 \mathrm{H}-3,140-142$ & 7.57 & 68.62 & 2.84 & 9.95 & 9.41 & 3.37 \\
\hline $2 \mathrm{H}-3,148-150$ & 7.64 & 68.27 & 2.13 & 13.24 & 4.49 & 1.65 \\
\hline $2 \mathrm{H}-4,0-2$ & 7.65 & 79.09 & 1.11 & 10.28 & 0.83 & 0.28 \\
\hline $2 \mathrm{H}-4,10-12$ & 7.77 & 54.65 & 0.51 & 6.30 & 6.64 & 1.19 \\
\hline $2 \mathrm{H}-4,16-18$ & 7.83 & 149.95 & 0.38 & 5.49 & 12.12 & 2.08 \\
\hline $2 \mathrm{H}-4,24-28$ & 7.91 & 27.52 & 0.61 & 8.35 & 9.26 & 0.76 \\
\hline $2 \mathrm{H}-4,32-34$ & 7.99 & 40.96 & 0.85 & 19.44 & 6.84 & 2.78 \\
\hline $2 \mathrm{H}-4,40-42$ & 8.07 & 13.51 & 0.91 & 11.08 & 9.41 & 3.19 \\
\hline $2 \mathrm{H}-4,48-50$ & 8.15 & 77.99 & 0.47 & 3.74 & 7.32 & 1.87 \\
\hline $2 \mathrm{H}-4,56-58$ & 8.23 & 78.85 & 1.52 & 6.31 & 10.61 & 1.01 \\
\hline $2 \mathrm{H}-4,64-66$ & 8.31 & 89.91 & 1.96 & 6.29 & 8.25 & 1.18 \\
\hline $2 \mathrm{H}-4,72-74$ & 8.39 & 242.59 & 1.67 & 8.53 & 7.79 & 1.67 \\
\hline $2 \mathrm{H}-4,80-82$ & 8.47 & 77.29 & 4.02 & 9.80 & 10.05 & 1.01 \\
\hline $2 \mathrm{H}-4,88-90$ & 8.55 & 26.49 & 3.73 & 18.05 & 9.75 & 2.07 \\
\hline $2 \mathrm{H}-4,96-98$ & 8.63 & 10.29 & 0.67 & 12.72 & 4.91 & 3.79 \\
\hline $2 \mathrm{H}-4,104-106$ & 8.71 & 21.31 & 0.18 & 25.85 & 3.59 & 2.15 \\
\hline $2 \mathrm{H}-4,112-114$ & 8.79 & 4.43 & 0.45 & 14.39 & 4.60 & 4.45 \\
\hline $2 \mathrm{H}-4,120-124$ & 8.87 & 4.78 & 0.25 & 15.95 & 3.54 & 4.56 \\
\hline $2 \mathrm{H}-4,128-130$ & 8.95 & 5.11 & 0.39 & 15.78 & 5.33 & 1.78 \\
\hline $2 \mathrm{H}-4,136-138$ & 9.03 & 7.19 & 0.33 & 10.67 & 4.76 & 6.24 \\
\hline $2 \mathrm{H}-4,144-146$ & 9.11 & 14.08 & 0.62 & 3.40 & 6.34 & 3.09 \\
\hline $2 \mathrm{H}-4,148-150$ & 9.15 & 18.23 & 0.41 & 5.59 & 10.14 & 2.48 \\
\hline
\end{tabular}

